\title{
HPV Replication Protein E1 Antibody
}

National Cancer Institute

\section{Source}

National Cancer Institute. HPV Replication Protein E1 Antibody. NCI Thesaurus. Code C124260.

Any immunog lobulin that recognizes human papillomavirus replication protein E1. 